\title{
Thermal Comfort While Sitting on Office Chairs - Subjective Evaluations
}

\section{Toplinska ugodnost sjedenja na uredskim stolcima - subjektivne procjene}

\author{
Original scientific paper • Izvorni znanstveni rad \\ Received-prispjelo: 16. 5. 2012. \\ Accepted-prihvaćeno: 15. 11. 2012. \\ UDK: $630 * 836 ; 630 * 882$ \\ doi: $10.5552 /$ drind.2012.1222
}

\begin{abstract}
Thermal comfort is related to human physiological reactions. In order to maintain a constant internal temperature, the human body must dissipate heat in a warm climate, and prevent heat losses in a cold climate. The overall sensation of comfort accompanies the warmest part of the body in a warm environment and the coldest one in a cold environment. Chair design and clothing may affect the difference in sensitivity between certain parts of the body, that is, they may affect thermal comfort. This research focused on subjective sensation of warmth and moisture while sitting on office chairs. The subjective method of evaluating thermal discomfort is based on ISO 7730:2005 standard, according to which a questionnaire was made for this research. Six subjects took part in the research. They were sitting on five different office chairs as they performed their usual jobs in controlled conditions. From the point of view of the evaluation of the sensation of warmth, all chairs were evaluated neutrally. The sensation under the buttocks and thighs was reported to be somewhat warmer, while the sensation on the back was reported to be somewhat colder, which was affected by the design of the back of the chair. No correlation has been proven between the actual temperature and moisture measurements and subjective evaluations of thermal comfort, in spite of a number of direct links. The use of the present method offers the possibility of further research into this subject, which would prove more thoroughly a correlation between design and construction solutions of office chairs and the comfort perceived by sitting persons.
\end{abstract}

Keywords: office chair, seating, sitting, thermal comfort, PU-foam, design, construction, subjective method.

SAŽETAK・ Toplinska ugodnost povezana je s fiziološkim reakcijama osoba. Kako bi zadržalo stalnu unutarnju temperaturu, tijelo mora oslobađati toplinu u toploj klimi, a sprečavati gubitke topline u hladnoj klimi. Ukupan osjećaj udobnosti prati najtopliji dio tijela u toplom okružju i najhladniji u hladnom okružju. Dizajn stolca i odjeća mogu utjecati na razliku u osjetljivosti između nekih dijelova tijela, odnosno mogu utjecati na toplinsku ugodnost. U radu su istraživani subjektivni osjećaji topline $i$ vlage pri sjedenju na uredskim radnim stolcima. Metoda subjektivne procjene toplinske udobnosti temelji se na normi ISO 7730:2005, prema kojoj je napravljen upitnik za ovo istraživanje. U ispitivanju je sudjelovalo šest ispitanika koji su sjedili na pet različitih uredskih stolaca za vrijeme obavljanja uobičajenih radnih zadataka u kontroliranim uvjetima. Sa stajališta procjene osjećaja topline, svi su stolci ocijenjeni neutralno. Ispod stražnjice i bedara osjećaj topline procijenjen je nešto većim, a osjećaj na leđima hladnijim, na što je utjecao dizajn naslona. Korelacije realnih mjerenja temperature i vlage sa subjektivnim procjenama toplinske udobnosti nisu dokazane, unatoč nekolikim izravnim poveznicama. Rad i prikazana metoda otvaraju mogućnost za daljnja istraživanja te problematike kojima bi se detaljnije dokazala korelacija između oblikovno-konstrukcijskih rješenja radnih stolaca i udobnosti sjedenja na njima.

Ključne riječi: uredski radni stolac, sjedenje, toplinska ugodnost, PU spužva, konstrukcije, oblikovanje, subjektivna metoda

\footnotetext{
Authors are assistant, assistant, assistant professor and professor at Faculty of Forestry, University of Zagreb, Zagreb, Croatia.

Autori su asistent, asistentica, docent i profesor Šumarskog fakulteta Sveučilišta u Zagrebu, Zagreb, Hrvatska.
} 


\section{INTRODUCTION}

\section{UVOD}

Thermal comfort is related to human physiological reactions. Humans are homeotherms - meaning that they attempt to maintain their internal (core) temperature within an optimum range (around $37^{\circ} \mathrm{C}$ ). The human body generates energy and exchanges it (absorbs or gives out) with the surroundings. In order to maintain its constant core temperature, the body must dissipate heat in a warm climate and prevent heat losses in a cold climate (Parsons, 2000). Comfort and sensation of individual body parts vary significantly, so that, in a cold climate, hands and feet are colder than the rest of the body parts. The head, which is insensitive to the cold, but sensitive to the warmth, is warmer than other parts of the body in a warm environment. The overall sensation of comfort accompanies the warmest local sensation (the head) in a warm environment and the coldest (hands and feet) in a cold environment. Chair design and clothing may affect the difference in sensitivity between the upper and lower part of the back. The lumbar region needs protection from cooling by good insulation or local warming. The thoracic region should have a possibility of dissipating body heat, i.e. of airing (Arens et al., 2006)

The human body generates thermal energy all the time (Grbac and Dalbelo-Bašć, 1994). The regulation of the normal physiological skin microclimate is necessary for the maintenance of the thermal equilibrium between the heat generated by inner metabolic physical processes and the heat lost from the skin in the surroundings (Nicholson et al., 1999; Hänel et al., 1997). In the early 1970s, Fanger found that being thermally neutral guarantees comfort, because in optimal condition, no specific sensation of feeling warm or cold is to be expected by the subjects (quoted in: Candas, 2005). However, this conclusion does not concern everyone. The same paper says that not being thermally neutral leads to discomfort. ISO 7730 standard, whose questionnaire served as the basis of this research, is based on Fanger's research, which, among other things, provides links to the number of individuals dissatisfied with regard to their thermal sensation, which are symmetric with regard to thermal neutrality.

The change of insulation around the body, i.e. taking off or changing the clothing with materials having poorer insulating abilities, affects thermal comfort. The design of office chairs may also affect thermal comfort. In the study with seven chairs in an air-conditioned room, researchers found insulating values to be in the range of $0.1 \mathrm{clo}^{1}$ for a net chair to 0.3 clo for a chair with the seat and the back of PU foam, which means that they are typical for the majority of modern office chairs (McCullough et al. (1994), quoted in: Hedge et $a l ., 2005)$. The comparison of three commercially available chairs (Brand et al., 2000) yielded indefinite results about the core temperature. Thermal conditions

\footnotetext{
Clo is a unit for measuring thermal isolation of clothes, and it

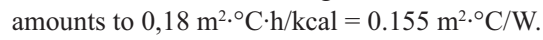

may differ if an individual is sitting on a chair with PU foam and high values of thermal insulation (clo) compared to a net chair with low values of thermal insulation. The development of gel production technology enabled the production of materials that give the body a sensation of feeling cold because of the more efficient withdrawal of heat from the body, increasing in this way the sensation of thermal comfort. During research into the influence of the design of ergonomic chairs on thermal comfort (Hedge et al., 2005), where influences of PU foam, net and gel in seats on thermal comfort and productivity were researched, its authors came to the conclusion that differences in insulating values of individual types of seat have no significant effects on thermal comfort in controlled climate conditions, and that they neither significantly affect productivity. The study found evidence of a gender difference in ratings of thermal comfort, with women reporting cooler conditions than men, with a 1.5 hours exposure to controlled climate conditions.

Lan et al. (2008) research into thermal comfort and gender differences also proved the existence of gender differences. Correlations of reported sensation of warmth, the air temperature and water vapor pressu-
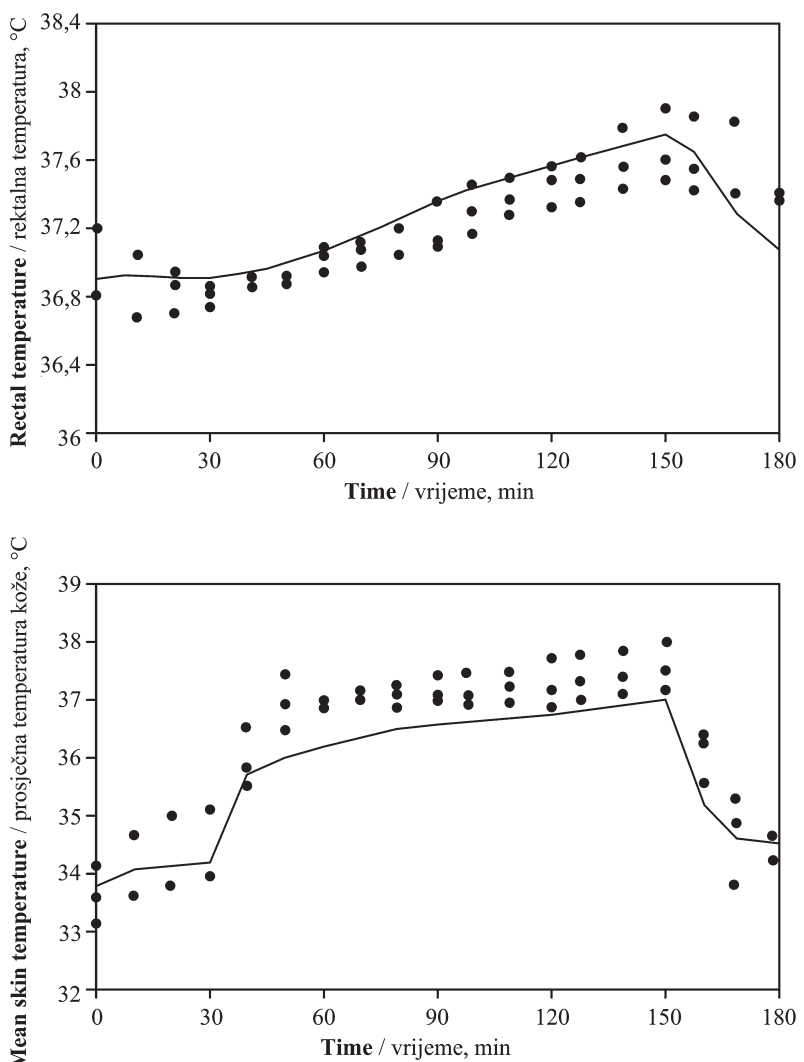

Figure 1 Comparison of the simulation (line) and the experimental results (dots) of a person in cotton clothes (cotton $100 \%, 0.195 \mathrm{~kg} / \mathrm{m}^{2}$ ), sitting during transition from $28{ }^{\circ} \mathrm{C}$ to $45^{\circ} \mathrm{C}$ and back to $28{ }^{\circ} \mathrm{C}$, RH $40 \%$ (source: $\mathrm{Xu}$ and Werner, 1997)

Slika 1. Usporedba simulacijskih (linija) i eksperimentalnih podataka (točke) osobe u pamučnoj odjeći (100 \% pamuk, $0,195 \mathrm{~kg} / \mathrm{m}^{2}$ ) pri sjedenju tijekom promjene temperature sa $28^{\circ} \mathrm{C}$ do $45^{\circ} \mathrm{C}$ i natrag, uz $40 \%$-tni RH (izvor: Xu i Werner, 1997) 
re showed that women are more sensitive to warmth and less to humidity than men. Analyses of subjective evaluations, the skin temperature and heartbeat variability, made within the same research, showed that females prefer neutral or slightly warmer conditions with regard to their permanently lower skin temperature and the fact, that the mean skin temperature is a good predictor for sensation and discomfort below the neutral. The comfortable operative temperature for women $\left(26.3{ }^{\circ} \mathrm{C}\right)$ is higher than the one for men $\left(25.3{ }^{\circ} \mathrm{C}\right)$, although both genders have almost the same neutral temperatures. Therefore, in the neutral area, i.e. in neutral conditions, there are no significant differences in the sensation of warmth with regard to gender. Research into changes of thermal insulation of a person while sitting showed that in case of office chairs, an insulation increase by $0.04-0.17$ clo depends on the height of the back of the chair and the seat thickness, while in case of a metal chair with a net or a wooden chair, a reduction in insulation of 0.03 clo was recorded. This can be explained by the fact that these chairs behave as "cooling flanges", rejecting the heat due to their high conductivity (Nilsson and Holmer, 1994). For a sitting individual, the chair may significantly affect the heat exchange and hence affect thermal comfort. In spite of these facts, literature on the influence of different seats on thermal insulation is scarce. A comparison between the thermal comfort of seat materials of different wheelchairs and office chairs showed that there are variations between chairs with regard to body parts touching the chair, i.e. the rear part of the thighs, the buttocks and the lower part of the back. With regard to the skin temperature of the subjects, there were no statistically significant differences between the chairs. A wheelchair with the PVC coating material was colder on the rear part of the thighs by some $0.4-0.8^{\circ} \mathrm{C}$ when compared to other wheelchairs, colder by $1.7^{\circ} \mathrm{C}$ than the office chairs (wool, viscose), and in the lumbar region by 1.1-1.3 ${ }^{\circ} \mathrm{C}$ than the rest. The same research showed that chair temperatures differed by $3.9^{\circ} \mathrm{C}$ between the warmest and the coldest part of the back and the seat. The wheelchair coated with PVC proved to be by far the most cold, while the office chairs proved to be by far the warmest statistically (Humphreys et al. 1998). The two most significant factors of the overall sensation of warmth were the person's activity and insulating abilities of clothing.

Zacharkow (1988) found that the resistance to the exchanges of heat and moisture acceptance and withdrawal on the area of contact between the body and the pad is strongly connected with the size of the contact area and the contact pressure. The sensation of comfort is, therefore, connected with the parameters of pressure, temperature and relative moisture on the point where the body and the pad touch. Therefore, upholstery materials must enable the transfer of moisture when touching the body. Hänel et al. (1997) showed that below a certain degree of compression, moisture and heat are mostly transported in the surface layer, while Shitzer et al. (1978) revealed that subjects determine the comfortable temperature for themselves according to variations of their own body temperature. "The ideal" environmental temperature varies from one person to another and in the course of time with regard to variations of the body temperature. Therefore, thermal comfort is related to the body temperature.

Moisture is, beside temperature, another important factor of comfort. Besides warmth, the human body constantly excretes moisture (liquid) through the skin. According to Reed et al. (1994), a sitting person perceives moisture on the skin surface as discomfort (quoted in: Stumpf et al., 2002), because wet skin increases the friction coefficient, causes sticking to clothing or chair upholstery and prevents small movements necessary to shift the weight from the pressure points (Hänel et al., 1997). Therefore, a moisture increase on the skin surface leads to uncomfortable sitting. The sleeping quality, for example, depends on materials touching the body, liquid absorption capacity and temperature (Grbac and Dalbelo-Bašić, 1994). Excessive skin hydration due to accumulated moisture changes its characteristics. Wet tissue is mechanically weaker than dry tissue (Park and Baddiel, 1972), which leads to increased wetting and wounds (decubitus ulcer). Moisture increases the resistance coefficient between the individual and the pad. Such increased resistance, when a patient is sliding against the bed sheet for example, may cause, together with a pressure increase, skin blisters and, finally, surface erosion (Sulzberger et al., (1966), Dinsdale (1974), quoted in: Nicholson et al., 1999). Research (Davies and Mills, 1999) into characteristics of slow regenerating foam with half-closed cells (mark CF-45) demonstrated that mechanical characteristics are very much dependant on temperature and humidity, but these effects were not researched in sitting experiments. Previous testing within research into the distribution of pressure while sitting on slow recovery PU foam (Davies et al., 2000) showed that, when a $25 \mathrm{~mm}$ thick layer of such foam is exposed to the temperature of $35^{\circ} \mathrm{C}$ and relative humidity of $80 \%$, it takes two hours for humidity contents to achieve equilibrium. It is probable that short sitting tests were mostly affected by air circulation, not so much by humidity input (Davies et al., 2000).

When it comes to thermal comfort, the emphasis is, therefore, on how to achieve and maintain thermal equilibrium of the body by changing postures. The posture in thermal comfort may be defined as resistant or compensational adjustment of different bodies to the partial change of the effective size of the body surface for heat exchange (Raja and Nicol, 1997). As far as the seat construction or structure is concerned, and taking into account climate and physiological facts, there are, according to Kurz et al. (1989), no significant differences between seats made entirely of foam and layered with springs, rubberized coconut fibers and coating materials. Seat and back upholstery of office chairs made of PU foam are usually covered with materials having insulating abilities and preventing in this way the withdrawal of heat from the body (quoted in Stumpf et al. 2002; Bartels, 2003). Nicholson at al. demonstrated to which extent foam limits heat transfer and that 
At this moment, how do you feel your...? / kakav osjećaj topline u vome trenutku imate...?

$\begin{array}{ccccccc}\begin{array}{c}\text { Cold } \\ \text { hladan }\end{array} & \begin{array}{c}\text { Cool } \\ \text { prohladan }\end{array} & \begin{array}{c}\text { Slightly cool } \\ \text { slabo prohladan }\end{array} & \begin{array}{c}\text { Neutral } \\ \text { neutralan }\end{array} & \begin{array}{c}\text { Slightly warm } \\ \text { malo topao }\end{array} & \begin{array}{c}\text { Warm } \\ \text { topao }\end{array} & \begin{array}{c}\text { Hot } \\ \text { vruć }\end{array} \\ 1 & 2 & 3 & 4 & 5 & 6 & 7 \\ 1 & 2 & 3 & 4 & 5 & 6 & 7 \\ 1 & 2 & 3 & 4 & 5 & 6 & 7 \\ 1 & 2 & 3 & 4 & 5 & 6 & 7 \\ 1 & 2 & 3 & 4 & 5 & 6 & 7 \\ 1 & 2 & 3 & 4 & 5 & 6 & 7 \\ 1 & 2 & 3 & 4 & 5 & 6 & 7 \\ 1 & 2 & 3 & 4 & 5 & 6 & 7 \\ 1 & 2 & 3 & 4 & 5 & 6 & 7 \\ 1 & 2 & 3 & 4 & 5 & 6 & 7\end{array}$

Figure 2 The first section of the questionnaire about thermal comfort with the answers-scores offered

Slika 2. Izgled prvog dijela upitnika o toplinskoj ugodnosti s ponuđenim brojčanim odgovorima

the cover is the limiting factor of the evaporation rate. Heat transfer is also limited by the resistance to imperceptible (latent) heat loss through the covers (Nicholson et al., 1999). PU foam pads also make moisture transfer from the skin surface more difficult. Diebschlag et al. (1988) revealed that besides different foam composition, its permeability depends on pressure, which signals that thermal comfort varies for different people using the same office chair, depending on where and how much they press the foamy seat and back upholstery. Fisher et al. (1978) studied different materials used for wheelchair seat cushions and found a significant rise in skin temperatures under the thighs and sitting bones of test subjects sitting on $10 \mathrm{~cm}$ thick foam rubber pads (quoted in: Stumpf et al., 2002).

The present research had two goals. The first was to explore thermo-physiological sensations on a selected number of subjects while sitting on different types of seats. In addition, the questionnaire was tested as well as its sensitivity in order to establish its reliability for future research of this type. The second goal of this research was to establish correlations between subjective and objective results into thermal comfort while sitting. Besides the basic research, in its last part, the paper presents the correlations with objective measurements of temperature and moisture while sitting on the same type of chair (results published by Vlaović et al., 2012).

\section{MATERIAL AND METHODS}

\section{MATERIJAL I METODE}

The method of subjective evaluation of thermal comfort is based on standard ISO 7730:2005 Moderate thermal environments - Determination of the PMV and PPD indices and specification of the conditions for thermal comfort, which describes how to measure thermal comfort by using a dummy or a person. The questionnaire for this research was modeled after it (Cengiz and Babalik, 2007).

The questionnaire was made up of four sections: sensation of warmth on ten different body regions, body moisture on two body regions, thermal comfort on a chair, and sweating level. Each of the four sections was developed as a scale offering a particular range of levels as possible answers (Vlaović, 2009).
"The warmth sensation scale" was, for instance, a seven-level scale (cold [1], cool [2], slightly cool [3], neutral [4], slightly warm [5], warm [6] and hot [7]) offering answers to the question: At this moment how do you feel your...? (Figure 2).

In order to make the understanding of the question easier, the warmth sensation section of the questionnaire was accompanied by a graphic presentation of the specific points on the body to which the question referred (Figure 3).

"The body moisture scale" consisted of four levels (dry [1], slightly wet [2], humid [3], and wet [4]) to answer the question How do you feel body moisture on your...? "The scale of thermal comfort on a chair" had three levels (low [1], medium [2], and good [3]) to answer the question How is comfort on...? "The sweating level scale" consisted of four answers (absent (1), low (2), medium (3), and much (4) to answer the question How is your sweat level? Each answer offered for a particular question from the above four groups was shown numerically and the subjects answered by circling the appropriate answer.

Number in the figure correspond to questions 1 to 8 , and represent the spot of heat feeling.

Broj na slici odgovara pitanjima od 1. do 8., a predstavlja mjesto osjećaja topline.

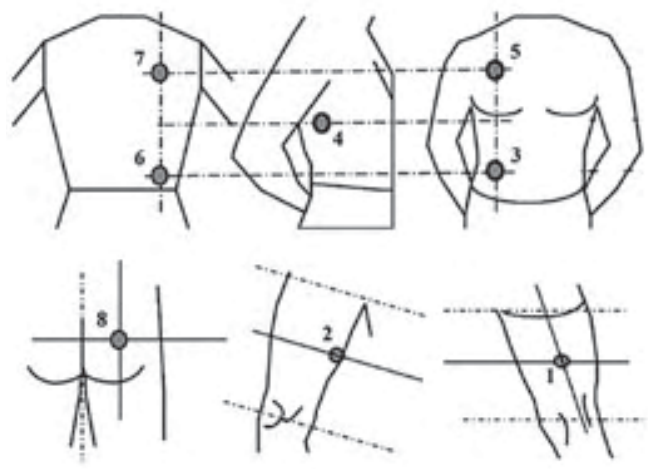

Figure 3 Schematic representation of a sense of warmth (source: Cengiz and Babalik, 2007)

Slika 3. Shematski prikaz mjesta osjećaja topline (izvor: Cengiz i Babalik, 2007) 


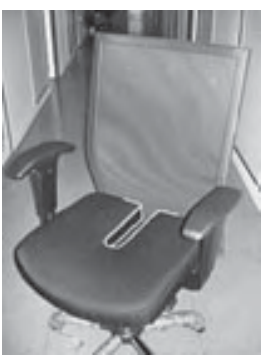

a) Model M1

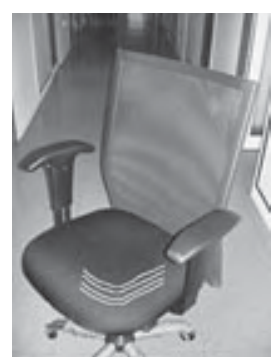

b) Model M2

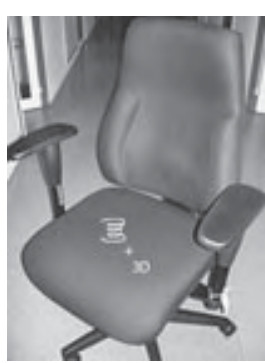

c) Model M3

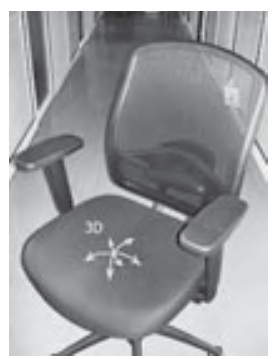

d) Model M4

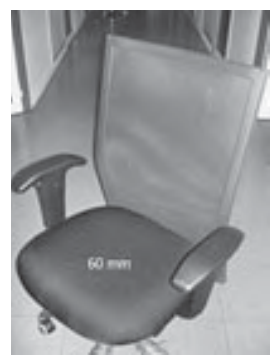

e) Model M5

Figure 4 Samples of office chairs

Slika 4. Uzorci uredskih radnih stolaca

Measurements were carried out in the air-conditioned room at the mean temperature of $23.94{ }^{\circ} \mathrm{C}$ and relative humidity of $46.43 \%$ throughout six days. According to the pre-determined schedule, six subjects were tested on five selected chairs, using two chairs per day, for 90 minutes each.

\subsection{Samples \\ 2.1. Uzorci}

The study used five models of office chairs (Figure 4). The samples were selected according to the principles of proper body support in the working posture and the constructions that enable proper and comfortable sitting posture as a pre-condition for comfort (Vlaović et al., 2008, Vlaović et al., 2010). In addition, attention was paid to compliance of the samples with the current standards regarding functional dimensions. Every sam- ple is detailed in Table 1. Cover material composition of all seats was $100 \%$ polyester, and seat thickness was 60 $\mathrm{mm}$ or $55 \mathrm{~mm}$ (models M3 and M4). Material make of all seats was non-hygroscopic. Detailed seat characteristics are presented in by Vlaović et al. (2012).

\subsection{Subjects \\ 2.2. Ispitanici}

The study included six healthy subjects. The subjects' details are given in the following table.

In order to minimize the influence of clothing, the subjects were wearing cotton underwear and light linen or cotton clothing. Prior to measurement, height of the seats and armrests had been tuned to every subject in order to ensure maximum comfort according to the table height, as required by the corresponding basic ergonomic criteria.

Table 1 Characteristics of seat construction of models of office chairs

Tablica 1. Konstrukcijska obilježja sjedala modela uredskih stolica

\begin{tabular}{|c|c|c|c|c|c|}
\hline Model & M1 & M2 & M3 & M4 & M5 \\
\hline $\begin{array}{l}\text { Seat } \\
\text { construction } \\
\text { konstrukcija } \\
\text { sjedala }\end{array}$ & $\begin{array}{l}\text { Slabstock foams: } \\
\text { rezana spužva: } \\
40 \mathrm{~mm} \text { PT3246*** } \\
20 \mathrm{~mm} \text { PG65120* }\end{array}$ & $\begin{array}{l}\text { Slabstock foams: } \\
\text { rezana spužva: } \\
20 \mathrm{~mm} \mathrm{VISCO} * * * \\
20 \mathrm{~mm} \text { PT3246** } \\
20 \mathrm{~mm} \text { PG65120* }\end{array}$ & $\begin{array}{l}\text { Molded PU-foam: } \\
\text { hladno lijevana spužva: } \\
10 \mathrm{~mm} \text { PU } 4040 * * * \\
45 \mathrm{~mm} \text { pocket springs } \\
\text { džepićaste opruge* } \\
\text { (D45 mm / r1.8 mm) }\end{array}$ & $\begin{array}{l}\text { Molded } \\
\text { PU-foam: } \\
\text { hladno lijevana } \\
\text { spužva: } \\
55 \mathrm{~mm} \text { PU } 4040\end{array}$ & $\begin{array}{l}\text { Slabstock } \\
\text { foam: } \\
\text { rezana spužva: } \\
60 \text { mm PT3246 }\end{array}$ \\
\hline $\begin{array}{l}\text { Total density } \\
\text { ukupna gustoća }\end{array}$ & $41.3 \mathrm{~kg} / \mathrm{m}^{3}$ & $48.5 \mathrm{~kg} / \mathrm{m}^{3}$ & $40 \mathrm{~kg} / \mathrm{m}^{3}$ & $40 \mathrm{~kg} / \mathrm{m}^{3}$ & $28.3 \mathrm{~kg} / \mathrm{m}^{3}$ \\
\hline
\end{tabular}

*** = upper layer material / materijal gornjeg sloja, $* *=$ middle layer material / materijal srednjeg sloja,

* = lower layer material / materijal donjeg sloja

Table 2 Anthropometric characteristics of subjects

Tablica 2. Antropometrijske osobine ispitanika

\begin{tabular}{|c|c|c|c|c|}
\hline $\begin{array}{l}\text { Subjects' code } \\
\text { Oznaka ispitanika }\end{array}$ & $\begin{array}{c}\text { Age, year } \\
\text { Starost, godine }\end{array}$ & $\begin{array}{c}\text { Height / Visina, } \\
\mathrm{cm}\end{array}$ & $\begin{array}{c}\text { Mass / Masa, } \\
\text { kg }\end{array}$ & $\begin{array}{l}\text { BMI, } \\
\mathrm{kg} / \mathrm{m}^{2}\end{array}$ \\
\hline Female 1 & 37 & 166 & 61 & 22.1 \\
\hline Female 2 & 43 & 164 & 70 & 26.0 \\
\hline Female 3 & 33 & 166 & 65 & 23.6 \\
\hline Male 4 & 29 & 182 & 68 & 20.5 \\
\hline Male 5 & 34 & 184 & 79 & 23.3 \\
\hline Male 6 & 34 & 181 & 91 & 27.8 \\
\hline Minimum & 29 & 164 & 61 & 20.53 \\
\hline Maximum & 43 & 184 & 91 & 27.78 \\
\hline Mean & 35 & 173.8 & 72.33 & 23.90 \\
\hline SD & 4.28 & 8.57 & 9.99 & 2.40 \\
\hline
\end{tabular}

Mean - arithmetical mean / aritmetička sredina; SD - standard deviation / standardna devijacija;

$\mathrm{BMI}$ - body mass index / indeks tjelesne mase 


\section{RESULTS AND DISCUSSION}

\section{REZULTATI I DISKUSIJA}

Subjective evaluations of thermal comfort by the selected sample of subjects while sitting on office chairs and performing their everyday jobs gave the results shown in the following tables.

Most subjects circled the neutral answer, i.e. mark four, when answering to the questions about the sensation of warmth on certain body part and the head. The average mark for answers given by the subjects is therefore 4.46. Looking at the values in Table 3, we notice somewhat higher average mark on points T1, T2 and T8 which represent sequentially the sensation of warmth under the thighs (5.40), the sensation of warmth on the inner thighs (4.74) and the sensation of warmth on the buttocks (5.37).

With regard to the sensation of moisture on the front and rear part of the torso and the sweating level of the whole body while sitting (Table 4), the answers are in the lower scale range of four levels. The marks for moisture on the torso are 1.17 and 1.23 (at the front and on the back). The average mark for the sweating level is 1.73. The lowest mark for the sweating level was given to the model M3 (1.33), and the highest to model M1 (2.00).

With regard to questions about the thermal comfort of the chair relating to the seat and the back (Table 4 ), the average mark given was 1.87 . The thermal com- fort of the seat (1.90) and the thermal comfort of the back (1.83) were marked approximately the same, while the highest average marks were given to the seat of the model M3 (2.33) and to the backs of models M1 (2.33) and M5 (2.00).

\subsection{Correlations between subjective evaluations of thermal comfort and objective temperature and moisture measurements}

3.1. Korelacije subjektivnih procjena toplinske udobnosti s objektivnim mjerenjima temperature i vlage

As described above, the questions from the questionnaire are related to the precisely determined points of sensation of warmth or moisture on the body. The questions about some sensations were directly related to probe locations, which measured the actual temperature and relative humidity occurrences while sitting. This especially concerns the following measuring points: T1 - At this moment how do you feel your under thigh?, T2 - At this moment how do you feel your inner thighs? and T8 - At this moment how do you feel your bottom? (Table 5).

After a thorough analysis and the determination of the non-existence of connections on the level of an individual seat, results were aggregated, which means that the average values of temperature and moisture, measured by 1-A, 3-B and 5-C probes, and measures of subjective evaluations of thermal comfort were determined.

Table 3 Subjective evaluations of chairs on points T1 to T8, of thermal sensation on the head and overall thermal sensation Tablica 3. Subjektivne procjene stolaca na točkama od T1 do T8, osjećaja topline na glavi i općeg osjećaja topline

\begin{tabular}{|c|c|c|c|c|c|c|c|c|c|c|c|}
\hline \multirow{2}{*}{ Model } & \multicolumn{11}{|c|}{$\begin{array}{l}\text { At this moment, how do you feel your...? } \\
\text { Kakav osjećaj topline u ovome trenutku imate...? }\end{array}$} \\
\hline & & T1 & $\mathbf{T 2}$ & T3 & T4 & T5 & T6 & $\mathbf{T 7}$ & T8 & \begin{tabular}{|c|} 
Head \\
Na glavi
\end{tabular} & $\begin{array}{l}\text { In general } \\
\text { Općenito }\end{array}$ \\
\hline \multirow{5}{*}{ M1 } & Mean & 5.50 & 5.00 & 4.50 & 4.33 & 4.17 & 4.50 & 4.33 & 5.33 & 4.33 & 4.67 \\
\hline & SEM & 0.22 & 0.37 & 0.34 & 0.21 & 0.17 & 0.34 & 0.61 & 0.21 & 0.21 & 0.33 \\
\hline & SD & 0.55 & 0.89 & 0.84 & 0.52 & 0.41 & 0.84 & 1.51 & 0.52 & 0.52 & 0.82 \\
\hline & Min & 5 & 4 & 4 & 4 & 4 & 4 & 3 & 5 & 4 & 4 \\
\hline & Max & 6 & 6 & 6 & 5 & 5 & 6 & 7 & 6 & 5 & 6 \\
\hline \multirow{5}{*}{ M2 } & Mean & 5.17 & 4.67 & 4.00 & 3.67 & 3.83 & 4.00 & 3.67 & 5.00 & 4.00 & 4.17 \\
\hline & SEM & 0.31 & 0.33 & 0.00 & 0.21 & 0.17 & 0.26 & 0.42 & 0.26 & 0.26 & 0.31 \\
\hline & SD & 0.75 & 0.82 & 0.00 & 0.52 & 0.41 & 0.63 & 1.03 & 0.63 & 0.63 & 0.75 \\
\hline & Min & 4 & 4 & 4 & 3 & 3 & 3 & 2 & 4 & 3 & 3 \\
\hline & Max & 6 & 6 & 4 & 4 & 4 & 5 & 5 & 6 & 5 & 5 \\
\hline \multirow{5}{*}{ M3 } & Mean & 5.33 & 4.67 & 4.00 & 4.33 & 3.67 & 4.17 & 5.33 & 5.67 & 4.33 & 4.33 \\
\hline & SEM & 0.33 & 0.33 & 0.26 & 0.21 & 0.21 & 0.31 & 0.33 & 0.42 & 0.21 & 0.33 \\
\hline & SD & 0.82 & 0.82 & 0.63 & 0.52 & 0.52 & 0.75 & 0.82 & 1.03 & 0.52 & 0.82 \\
\hline & Min & 4 & 4 & 3 & 4 & 3 & 3 & 4 & 4 & 4 & 3 \\
\hline & Max & 6 & 6 & 5 & 5 & 4 & 5 & 6 & 7 & 5 & 5 \\
\hline \multirow{5}{*}{ M4 } & Mean & 5.67 & 4.67 & 4.50 & 4.00 & 4.00 & 4.00 & 3.33 & 5.33 & 4.00 & 4.33 \\
\hline & SEM & 0.33 & 0.33 & 0.34 & 0.52 & 0.26 & 0.26 & 0.56 & 0.56 & 0.26 & 0.42 \\
\hline & SD & 0.82 & 0.82 & 0.84 & 1.26 & 0.63 & 0.63 & 1.37 & 1.37 & 0.63 & 1.03 \\
\hline & Min & 5 & 4 & 4 & 2 & 3 & 3 & 1 & 3 & 3 & 3 \\
\hline & Max & 7 & 6 & 6 & 6 & 5 & 5 & 5 & 7 & 5 & 6 \\
\hline \multirow{5}{*}{ M5 } & Mean & 5.33 & 4.67 & 4.17 & 4.17 & 3.67 & 4.17 & 4.17 & 5.50 & 4.33 & 4.50 \\
\hline & SEM & 0.33 & 0.33 & 0.17 & 0.17 & 0.42 & 0.31 & 0.40 & 0.34 & 0.42 & 0.34 \\
\hline & SD & 0.82 & 0.82 & 0.41 & 0.41 & 1.03 & 0.75 & 0.98 & 0.84 & 1.03 & 0.84 \\
\hline & Min & 4 & 4 & 4 & 4 & 2) & 3 & 3 & 4 & 3 & 4 \\
\hline & Max & 6 & 6 & 5 & 5 & 5 & 5 & 6 & 6 & 6 & 6 \\
\hline
\end{tabular}

T1 - Under thigh / ispod bedara; T2 - Inner thighs / unutar bedara; T3 - Stomach / u području trbuha; T4 - Side of body / na bočnim stranama tijela; T5 - Chest / u području prsa; T6 - Waist / u području struka; T7 - Back / na leđima; T8 - Bottom /na stražnjici 
........ Vlaović, Domljan, Župčić, Grbac: Thermal Comfort While Sitting on Office Chairs...

Table 4 Subjective evaluations of chairs according to the sensation of moisture, thermal comfort and sweating level

Tablica 4. Subjektivne procjene stolaca prema osjećaju vlažnosti, toplinskoj ugodnosti i stupnju znojenja

\begin{tabular}{|c|c|c|c|c|c|c|}
\hline \multirow{2}{*}{ Model } & \multicolumn{3}{|c|}{$\begin{array}{c}\text { How do you feel body moisture on your...? } \\
\text { Kakav osjećaj tjelesne vlage imate na...? }\end{array}$} & \multicolumn{2}{|c|}{$\begin{array}{l}\text { How is comfort on...?? } \\
\text { Kakva je ugodnost na...? }\end{array}$} & \multirow{2}{*}{$\begin{array}{c}\text { How is your...? } \\
\text { Kakav je vaš...? } \\
\text { Sweat level } \\
\text { Stupanj znojenja }\end{array}$} \\
\hline & & $\begin{array}{c}\text { Torso front } \\
\text { Prednjem torzu }\end{array}$ & $\begin{array}{c}\text { Torso back } \\
\text { Stražnjem torzu }\end{array}$ & $\begin{array}{l}\text { Seat back } \\
\text { Naslonu }\end{array}$ & $\begin{array}{l}\text { Seat cushion } \\
\text { Sjedalu }\end{array}$ & \\
\hline \multirow{5}{*}{ M1 } & Mean & 1.17 & 1.33 & 2.00 & 2.00 & 2.00 \\
\hline & SEM & 0.17 & 0.33 & 0.37 & 0.00 & 0.45 \\
\hline & SD & 0.41 & 0.82 & 0.89 & 0.00 & 1.10 \\
\hline & Min & 1 & 1 & 1 & 2 & 1 \\
\hline & Max & 2 & 3 & 3 & 2 & 3 \\
\hline \multirow{5}{*}{ M2 } & Mean & 1.00 & 1.00 & 1.83 & 1.67 & 1.83 \\
\hline & SEM & 0.00 & 0.00 & 0.31 & 0.21 & 0.31 \\
\hline & SD & 0.00 & 0.00 & 0.75 & 0.52 & 0.75 \\
\hline & Min & 1 & 1 & 1 & 1 & 1 \\
\hline & Max & 1 & 1 & 3 & 2 & 3 \\
\hline \multirow{5}{*}{ M3 } & Mean & 1.17 & 1.50 & 2.33 & 1.67 & 1.33 \\
\hline & SEM & 0.17 & 0.22 & 0.33 & 0.21 & 0.21 \\
\hline & SD & 0.41 & 0.55 & 0.82 & 0.52 & 0.52 \\
\hline & Min & 1 & 1 & 1 & 1 & 1 \\
\hline & Max & 2 & 2 & 3 & 2 & 2 \\
\hline \multirow{5}{*}{ M4 } & Mean & 1.33 & 1.17 & 1.83 & 1.83 & 1.83 \\
\hline & SEM & 0.21 & 0.17 & 0.31 & 0.17 & 0.17 \\
\hline & SD & 0.52 & 0.41 & 0.75 & 0.41 & 0.41 \\
\hline & Min & 1 & 1 & 1 & 1 & 1 \\
\hline & Max & 2 & 2 & 3 & 2 & 2 \\
\hline \multirow{5}{*}{ M5 } & Mean & 1.17 & 1.17 & 1.50 & 2.00 & 1.67 \\
\hline & SEM & 0.17 & 0.17 & 0.22 & 0.00 & 0.21 \\
\hline & SD & 0.41 & 0.41 & 0.55 & 0.00 & 0.52 \\
\hline & Min & 1 & 1 & 1 & 2 & 1 \\
\hline & Max & 2 & 2 & 2 & 2 & 2 \\
\hline
\end{tabular}

Mean - arithmetical mean / aritmetička sredina; SEM - standard error of arithmetic mean / standardna pogreška aritmetičke sredine; $\mathrm{SD}$ - standard deviation / standardna devijacija

Table 5 Correlation between thermal comfort and the values of temperature and moisture measurements

Tablica 5. Povezanost toplinske ugodnosti s izmjerenim vrijednostima temperature i vlage

\begin{tabular}{|c|c|c|c|c|}
\hline \multicolumn{2}{|c|}{$\begin{array}{c}\text { Probe } \\
\text { Sonda }\end{array}$} & \multicolumn{3}{c|}{ Measurement points / Mjerne točke } \\
\cline { 2 - 5 } & $\mathrm{T} 1$ & $\mathrm{~T} 2$ & $\mathrm{~T} 8$ \\
\hline $3-\mathrm{B}$ & $r$ & .762 & -.175 & .626 \\
\cline { 2 - 5 } $\mathrm{t},{ }^{\circ} \mathrm{C}$ & $p$ & $.078^{* *}$ & .740 & .183 \\
\hline $3-\mathrm{B}$ & $r$ & -.249 & -.110 & -.319 \\
\cline { 2 - 5 }$\%, \mathrm{RH}$ & $p$ & .634 & .835 & .538 \\
\hline $5-\mathrm{C}$ & $r$ & .580 & -.199 & .447 \\
\cline { 2 - 5 } $\mathrm{t},{ }^{\circ} \mathrm{C}$ & $p$ & .227 & .706 & .374 \\
\hline $5-\mathrm{C}$ & $r$ & .455 & -.439 & .306 \\
\cline { 2 - 5 }$\%, \mathrm{RH}$ & $p$ & .365 & .384 & .555 \\
\hline \multirow{2}{*}{$1-\mathrm{A}$} & $r$ & .649 & -.379 & .478 \\
$\mathrm{t},{ }^{\circ} \mathrm{C}$ & $p$ & .163 & .458 & .337 \\
\hline $1-\mathrm{A}$ & $r$ & -.002 & -.222 & -.099 \\
\cline { 2 - 5 }$\%, \mathrm{RH}$ & $p$ & .997 & .672 & .853 \\
\hline
\end{tabular}

** significant difference of $10 \%$ / razlika značajna na razini od $10 \%$

Note: Probe 1-A $\left(\mathrm{t}^{\circ} \mathrm{C}\right)$ and $(\% \mathrm{RH})$ : temperature and moisture under the gluteus on the seat; Probe $3-\mathrm{B}\left(t,{ }^{\circ} \mathrm{C}\right)$ and $(\% \mathrm{RH})$ : temperature and moisture under the thigh on the seat; Probe $5-\mathrm{C}\left(t,{ }^{\circ} \mathrm{C}\right)$ and $(\% \mathrm{RH})$ : temperature and moisture in the centre of the seat between the lower extremities; $\mathrm{r}$ - Pearson's coefficient of correlation; $p$ - difference significance (because of the small number of subjects in experiment, a milder significance criterion was applied i.e. $\mathrm{p}<0.10)$; $\mathrm{T} 1$ - Under thigh; T2 - Inner thighs; T8 - Bottom / Napomena: Sonda 1-A $\left(t,{ }^{\circ} C\right) i(\%$ $R H)$ : temperatura i vlaga ispod gluteusa na sjedalu; sonda $3-B\left(t,{ }^{\circ} \mathrm{C}\right)$ $i(\% R H)$ : temperatura $i$ vlaga ispod natkoljenice na sjedalu; sonda 5-C $\left(t{ }^{\circ} \mathrm{C}\right)$ i $(\%$ RH): temperatura $i$ vlaga na sredini sjedala, između nogu ispitanika; $r$-Pearsonov koeficijent korelacije; $p$ - razina značajnosti (zbog malog broja ispitanika primijenjen je niži kriterij značajnosti od $10 \%$ ); T1 - ispod bedara; T2 - unutar bedara; T8 - na stražnjici.
A correlation was calculated between the said measures, which showed that the temperature measured in the region under the thighs on the seat (3-B) is related to the subjective temperature evaluation in the region under the thighs (T1). The correlation is high and positive, meaning that the higher measured temperature values were perceived as higher by subjects as well $(r=0.762$; $p=0.078)$. In other cases, the correlation level obtained is not statistically significant $(p>0.10)$.

It is interesting that other correlations did not show any significance. This especially applies to the lack of correlation between T8 and 1-A, although the average rating on $\mathrm{T} 8$ is relatively high, as well as the aggregated temperature value of the probe 1-A (it was higher than the temperature of the probe 5-C, but lower than the temperature of the probe 3-B).

This discrepancy could be due to several reasons: because of the constitution and gender differences that have different perceptions of thermal comfort; due to the relatively short sitting; because of the relatively small number of respondents, and thus the small number of data whose differences did not prove significant.

\section{CONCLUSION \\ 4. ZAKLJUČAK}

Based on the research undertaken on six subjects and based on its results, the following may be concluded: 
- From the point of view of the evaluation of the sensation of warmth, all chairs have been neutrally evaluated. The sensation under the buttocks and thighs have been reported to be somewhat warmer, while those on the back have been reported to be somewhat colder. This is understandable with regard to the net construction of the back of the chair.

- It can be concluded that the questionnaire is sufficiently sensitive and reliable for such studies, but testing time should be longer than $1.5 \mathrm{~h}$.

- In this research no correlation has been proven between the actual temperature and relative humidity measurements and subjective evaluations of thermal comfort, although there have several directly linked points.

- All correlations obtained are of low or only of medium intensity and are not significant. Since the experiment included only 6 subjects, a milder significance criterion was applied i.e. $p<0.10$. Therefore, no valid conclusions can be reached based on these relations.

- Henceforward, accuracy and reliability of the measurement technique should be increased. It could be said that the use of this system in the seats with thin upholstery is limited. Namely, probe size is relatively large with respect to the thickness of the seat, and therefore horizontal embedding is needed to avoid "moving" from the defined measuring point (see paper: Vlaović et al. (2012), Fig. 3b).

- Future research should include a greater number of subjects as well as different types of design and construction solutions for office chairs, since the selected method and the questionnaire proved appropriate for research and for obtaining relevant results.

\section{REFERENCES}

\section{LITERATURA}

1. Arens, E.; Zhang, H.; Huizenga, C., 2006: Partial- and whole-body thermal sensation and comfort - Part I: Uniform environmental conditions. Journal of Thermal Biology 31: 53-59

http://dx.doi.org/10.1016/j.jtherbio.2005.11.028.

2. Bartels, V. T., 2003: Thermal comfort of airplane seats: Influence of different seat materials and the use of laboratory test methods, technical note. Applied Ergonomics 34: 393-399

http://dx.doi.org/10.1016/S0003-6870(03)00058-9.

3. Candas, V., 2005: To be or not to be comfortable: Basis and prediction. Environmental ergonomics: The ergonomics of human comfort, health and performance in the thermal environment, Tochihara, Y. and Ohnaka, T. (ed.), Elsevier ergonomics book series Volume 3, Elsevier Ltd.: 207-215.

4. Cengiz, T. G.; Babalık, F. C., 2007: An on-the-road experiment into the thermal comfort of car seats, Applied Ergonomics 38: 337-347 http://dx.doi.org/10.1016/j.apergo.2006.04.018.

5. Davies, O.; Gilchrist, A.; Mills, N. J., 2000: Seating pressure distribution using slow-recovery polyurethane foams. Cellular Polymers 19(1): 1-24.

6. Grbac, I.; Dalbelo-Bašić, B., 1994: Data analysis of thermal conductivity and moisture permeability in mattress. Proceedings of the 16th international conference on Information technology interfaces, Pula June 14-17. University Computing Centre, Zagreb, Croatia: 217-222.
7. Hänel, S.-E.; Dartman, T.; Shishoo, R., 1997: Measuring methods for comfort rating of seats and beds. International journal of Industrial Ergonomics 20: 163-172 http://dx.doi.org/10.1016/S0169-8141(96)00049-2.

8. Hedge, A.; Saito, M.; Jagdeo, J., 2005: Does ergonomic chair design affect thermal comfort?. Proceedings of the Human factors and ergonomics society 49th annual meeting: 793-797.

9. Humphreys, N.; Webb, L. H.; Parsons, K. C., 1998: A comparison of the thermal comfort of different wheelchair seating materials and an office chair. Contemporary Ergonomics 1998. Hanson, M.A. (ed), Taylor and Francis, Ergonomics Society Annual Conference, Cirencester, UK, April 1998: 525-529.

10. Kurz, B.; Diebschlag, W.; Heidinger, F., 1989: Recommendation for ergonomic and climatic physiological vehicle seat design. Journal of Cellular Plastics 25: 125-137 http://dx.doi.org/10.1177/0021955X8902500203.

11. Lan, L.; Lian, Z.; Liu, W.; Liu, Y., 2008: Investigation of gender difference in thermal comfort for Chinese people. Eur J Appl Physiol 102: 471-480 http://dx.doi.org/10.1007/s00421-007-0609-2.

12. Nicholson, G. P.; Scales, J. T.; Clark, R. P.; de CalcinaGoff, M. L., 1999: A method for determining the heat transfer and water vapour permeability of patient support systems. Medical Engineering \& Physics 21: 701-712 http://dx.doi.org/10.1016/S1350-4533(00)00003-5.

13. Nilsson, H.; Holmér, I., 1994: Changes in thermal insulation for seated persons. International Congress on Physiological Anthropology, Kiel: 326-329.

14. Parsons, K. C., 2000: Environmental ergonomics: A review of principles, methods and models. Applied Ergonomics 31: 581-594 http://dx.doi.org/10.1016/S0003-6870(00)00044-2.

15. Raja, I. A.; Nicol, F., 1997: A technique for recording and analysis of postural changes associated with thermal comfort. Applied Ergonomics 28 (3): 221-225 http://dx.doi.org/10.1016/S0003-6870(96)00036-1.

16. Stumpf, B.; Chadwick, D.; Dowell, B., 2002: The attributes of thermal comfort, ergonomic criteria for the design of the Aeron ${ }^{\circledR}$ chair, Herman Miller Inc., U.S.A., www.hermanmiller.com

17. Vlaović, Z.; Bogner, A.; Grbac, I., 2008: Comfort evaluation as the example of anthropotechnical furniture design. Coll. Antropol. 32(1): 277-283.

18. Vlaović, Z., 2009: Comfort factors of office chairs (Doctoral thesis, in Croatian). University of Zagreb, Faculty of Forestry, Zagreb.

19. Vlaović, Z.; Grbac, I.; Domljan, D.; Bublić, A., 2010: Office work chairs - research of deformations and comfort indeks (In Croatian). Drvna ind. 61(3): 159-168.

20. Vlaović, Z.; Domljan, D.; Grbac, I., 2012: Research of temperature and moisture during sitting on office chairs. Drvna ind. 63(2): 105-112.

21. Xu, X.; Werner, J., 1997: A dynamic model of the human/ clothing/environment-system. Applied Human Science, Journal of physiological anthropology 16 (2): 61-75.

\section{Corresponding address:}

Assistant ZORAN VLAOVIĆ, Ph.D.

Faculty of Forestry

University of Zagreb

HR-10000 Zagreb, CROATIA

e-mail: vlaovic@sumfak.hr 